\title{
Diversity and abundance of aerobic anoxygenic phototrophic bacteria in two cyanobacterial bloom-forming lakes in China
}

\author{
Limei Shi ${ }^{1,2}$, Yuanfeng Cai ${ }^{1,2}$, Zhuting Chen ${ }^{1}$, Yawei Zhou ${ }^{1}$, Pengfu Li ${ }^{1 *}$ and Fanxiang Kong ${ }^{2 *}$ \\ 1 State Key Laboratory of Pharmaceutical Biotechnology, School of Life Sciences, Nanjing University, Nanjing 210093, P. R. China \\ 2 State Key Laboratory of Lake Science and Environment, Nanjing Institute of Geography and Limnology, Chinese Academy \\ of Sciences, 73 East Beijing Road, Nanjing 210008, P. R. China
}

Received 21 June 2010; Accepted 19 August 2010

\begin{abstract}
Aerobic anoxygenic phototrophic (AAP) bacteria are widely distributed in marine and freshwater ecosystems. The aims of this study were to investigate the diversity and abundance of AAP bacteria in cyanobacterial bloom-forming eutrophic lakes and to study the association of AAP bacteria with the bloomforming cyanobacteria. Analysis of $p u f M$ gene (the light-reaction center gene) clone libraries indicated that in eutrophic lakes (Lake Taihu and Lake Chaohu, China) with cyanobacterium Microcystis blooms, the AAP bacteria were related to members of Alphaproteobacteria, Betaproteobacteria, and Gammaproteobacteria. In Lake Taihu and Lake Chaohu, Alphaproteobacteria accounted for $81.5 \%$ and $75.0 \%$ of Microcystisassociated AAP bacteria, respectively, and $84.6 \%$ and $72.5 \%$ of free-living AAP bacteria, respectively. The predominance of Alphaproteobacteria in the two lakes was different from the previously reported predominance of Betaproteobacteria in freshwater lakes. Quantitative real-time PCR analysis indicated that in Lake Taihu and Lake Chaohu, AAP bacteria represented an important part of the bacterial community associated with Microcystis, and the abundance of Microcystis-associated AAP bacteria (18.3\% and $11.7 \%$, respectively) was higher than that of free-living AAP bacteria (5.1\% and 7.9\%, respectively). The abundance of AAP bacteria in the two bloom-forming lakes was higher than the previously reported level in other eutrophic freshwater bodies.
\end{abstract}

Key words: Bacteria / China / lakes / Microcystis / pufM gene

\section{Introduction}

Aerobic anoxygenic phototrophic (AAP) bacteria are strict aerobes capable of utilizing light as an energy source without producing molecular oxygen while assimilating organic matter for carbon and energy (Eiler, 2006). AAP bacteria are widely distributed in both marine and freshwater environments, and may comprise a large fraction of the bacterioplanktonic community (Lami et al., 2007). AAP bacteria may alter current models of the carbon cycle and other biogeochemical processes (Karl, 2002).

Phylogenetic analysis based on pufM and other photosynthesis genes suggests that Alphaproteobacterial and Gammaproteobacterial AAP bacteria are abundant in oceans and saline lakes, whereas Betaproteobacteria are predominant in freshwater bodies (Yurkova et al., 2002; Allgaier et al., 2003; Karr et al., 2003; Waidner and Kirchman, 2005, 2007, 2008; Jiang et al., 2009). The

\footnotetext{
*Corresponding authors: pengfuli@nju.edu.cn,
} fxkong@niglas.ac.cn discovery of AAP bacteria in open seas suggests that AAP bacteria can adapt to oligotrophic waters because light might provide supplementary energy in low-nutrient conditions (Kolber et al., 2000, 2001). However, recent data indicate that AAP bacteria are abundant in mesotrophic coastal and estuarine environments (Schwalbach and Fuhrman, 2005; Cottrell et al., 2006). In temperate freshwater systems, AAP bacteria have been found to be abundant in several oligotrophic and mesotrophic lakes, while in more eutrophic water bodies, they represent a negligible part of the total microbial community (Mašín et al., 2008).

Blooms of cyanobacteria Microcystis spp. occur in temperate eutrophic lakes all over the world. Large quantities of bacteria have been found to be associated with field-grown Microcystis colonies (Worm and Søndergaard, 1998; Brunberg, 1999). The aims of this study were to determine the diversity and abundance of AAP bacteria in cyanobacterial bloom-forming lakes and to study the association of AAP bacteria with the bloomforming cyanobacteria. To our knowledge, this is the first 
report on the diversity and abundance of AAP bacteria in cyanobacterial bloom-forming eutrophic lakes.

\section{Materials and methods}

\section{Collection of samples and DNA extraction}

In the summer of 2008, triplicate water samples were collected from one site with a cyanobacterial bloom in each lake (Meiliang Bay of Lake Taihu, and Shuangqiao Estuary of Lake Chaohu, China). The samples were collected from surface waters (top $50 \mathrm{~cm}$ ) with a $2.5 \mathrm{~L}$ Schindler sampler and transported to the lab within $3 \mathrm{~h}$. The Microcystis colonies were obtained by filtrating the water samples with $40 \mu \mathrm{m}$ mesh size nylon screen (Shangyu Daoxu Zhangxing Screen Factory, Zhejiang, China). To remove free-living bacteria, the collected colonies were washed aseptically 10 times on autoclaved $20 \mu \mathrm{m}$ pore size nylon screen with sterile phosphate buffered saline (PBS). To obtain free-living bacteria, the water samples were pre-filtered through a $3 \mu \mathrm{m}$ pore-size membrane to eliminate Microcystis cells, and then the bacteria were harvested by centrifugation at $15000 \times g$ for $10 \mathrm{~min}$. Before the geochemical parameters of the lake waters were measured, water samples were filtered through $0.22 \mu \mathrm{m}$ pore-size membranes. Total dissolved nitrogen (TDN) and total dissolved phosphorus (TDP) were measured according to standard methods (Jin and Tu, 1990). Total organic carbon (TOC) content was determined with a TOC analyzer (Shimadzu TOC-5000A) following the manufacturer's instructions. The dominance of Microcystis spp. in the collected biomass was examined with a light microscope (Nikon, YS2-H, China). Morphological classification of cyanobacteria and other algae was conducted according to $\mathrm{Hu}$ and Wei (2006). DNA extraction of bacterial community was conducted using the potassium xanthogenate sodium dodecyl sulfate (XS procedure) method according to Tillett and Neilan (2000).

\section{Clone libraries of pufM gene}

Four pufM gene libraries were constructed. FT and FC were clone libraries of free-living AAP bacteria from Lake Taihu and Lake Chaohu, respectively. AT and AC were clone libraries of AAP bacteria associated with Microcystis colonies from Lake Taihu and Lake Chaohu, respectively. The primer set of pufM forward 557 (5'-TACGGSAACCTGTWCTAC-3') and pufM reverse 750 (5'-CCATSGTCCAGCGCCAGAA-3') were used for PCR amplification of partial sequences of the puf $M$ gene (Hu et al., 2006). Amplification conditions consisted of denaturation of $94^{\circ} \mathrm{C}$ for $4 \mathrm{~min}$, followed by 30 cycles of $94{ }^{\circ} \mathrm{C}$ for $1 \mathrm{~min}, 52^{\circ} \mathrm{C}$ for $1 \mathrm{~min}$, and $72^{\circ} \mathrm{C}$ for $1 \mathrm{~min}$, and extension at $72{ }^{\circ} \mathrm{C}$ for $5 \mathrm{~min}$. Reaction mixture contained final concentration of reagents as follows: $1 \mathrm{X}$ PCR buffer (without $\mathrm{Mg}^{2+}$ ), $2.5 \mathrm{mM} \mathrm{MgCl}_{2}, 0.2 \mathrm{mM}$ of each deoxynucleotide triphosphate, $0.2 \mu \mathrm{M}$ of each primer, $2.5 \mathrm{U}$ Taq DNA polymerase (Takara), and 20 to $50 \mathrm{ng}$ genomic DNA template. PCR products for each library were pooled and gel-purified using a QIAquick PCR Purification Kit (Sangon Valencia, CA, USA). Ligation into pGEM-T vector (Promega) was performed at $4{ }^{\circ} \mathrm{C}$ overnight. Ligation products were transformed into competent Escherichia coli cells. All clone libraries were screened for inserts using colony PCR with pGEM-T vector primers T7 (5'-TACGACTCACTATAGGGCGA3') and SP6 (5'-TAGGTGACACTATAGAATAC-3'). For each library, recombinant plasmids of randomly selected clones were extracted and sequenced on an ABI 3730xl DNA Analyzer using the primer T7 at Shanghai Sangon Biological Engineering Technology Limited Company, China. Clone sequences showing more than $97 \%$ similarity were considered to be of the same group (Jiao et al., 2007). One sequence from each group was selected as a representative for phylogenetic analysis. The sequences were deposited in the GenBank database under the accession numbers: FJ589072-FJ589076, FJ589078-FJ589080, FJ589082-FJ589091, FJ589093FJ589094, FJ589096-FJ589114, and FJ589118-FJ589128.

\section{Abundance of AAP bacteria}

Samples of free-living bacteria and Microcystis colonies from the two lakes were subjected to real-time quantitative PCR (qPCR) analysis to quantify copies of pufM gene and bacterial 16S rRNA gene. Samples of the Microcystis colonies were also subjected to qPCR analysis to quantify copies of Microcystis-specific 16S rRNA gene. The abundance of cells with these target genes in the original samples were inferred from these qPCR results. The cells with the bacterial 16S rRNA gene included Microcystis cells, thus the number of bacteria associated with Microcystis was obtained by subtracting the copies of Microcystis-specific 16S rRNA gene from copies of bacterial 16S rRNA gene.

qPCR was conducted with an ABI PRISM 7000 sequence detection system (Applied Biosystems, Darmstadt, Germany) using SYBR Green PCR Master Mix kit (QIAGEN, Valencia, CA). All reactions were carried out in a total volume of $25 \mu \mathrm{L}$. All samples were amplified in triplicate. Using the primer set of pufM forward 557 and $p u f M$ reverse 750, the pufM gene was amplified under the following conditions: denaturation at $94{ }^{\circ} \mathrm{C}$ for $4 \mathrm{~min}$, followed by 40 cycles of $94{ }^{\circ} \mathrm{C}$ for $1 \mathrm{~min}$, $52^{\circ} \mathrm{C}$ for $1 \mathrm{~min}$, and $72^{\circ} \mathrm{C}$ for $1 \mathrm{~min}$, and extension at $72^{\circ} \mathrm{C}$ for $5 \mathrm{~min}$. Using the universal bacterial primer pair Bac331F (5'-TCCTACGGGAGGCAGCAGT-3')/ Bac797R (5'-GGACTACCAGGGTCTAATCCTGTT-3') (Nadkarni et al., 2002), amplification of the bacterial 16S rRNA gene was conducted under the following conditions (Jiang et al., 2007): $95^{\circ} \mathrm{C}$ for $15 \mathrm{~min}$, followed by 45 cycles of $94^{\circ} \mathrm{C}$ for $15 \mathrm{~s}, 54^{\circ} \mathrm{C}$ for $30 \mathrm{~s}$, and $72^{\circ} \mathrm{C}$ for $30 \mathrm{~s}$. Using the primer pair MICR 184F (5'GCCGCRAGGTGAAAMCTAA-3') and MICR 431R 
Table 1. Geochemical parameters of collected water samples from Lake Taihu and Lake Chaohu.

\begin{tabular}{|c|c|c|c|c|c|c|c|c|c|}
\hline Location & $\mathrm{pH}$ & Temperature & $\begin{array}{c}\text { DOC } \\
\left(\mathrm{mg}^{-L^{-1}}\right)\end{array}$ & $\begin{array}{c}\text { TDP } \\
\left(\mathrm{mg}^{-L^{-1}}\right)\end{array}$ & $\begin{array}{c}\mathrm{PO}_{4}-\mathrm{P} \\
\left(\mu \mathrm{g} . \mathrm{L}^{-1}\right)\end{array}$ & $\begin{array}{c}\text { TDN } \\
\left(\mathrm{mg}^{\left.-\mathrm{L}^{-1}\right)}\right.\end{array}$ & $\begin{array}{c}\mathrm{NO}_{\mathrm{X}^{-} \mathrm{N}} \\
\left(\mathrm{mg} . \mathrm{L}^{-1}\right)\end{array}$ & $\begin{array}{c}\mathrm{NH}_{4}-\mathrm{N} \\
\left(\mathrm{mg} . \mathrm{L}^{-1}\right)\end{array}$ & $\begin{array}{c}\text { Chl } a \\
\left(\mu \mathrm{g} . \mathrm{L}^{-1}\right) \\
\end{array}$ \\
\hline Lake Taihu & 8.52 & 28.2 & 7.49 & 0.13 & 14.15 & 1.37 & 0.62 & 0.06 & 36.75 \\
\hline Lake Chaohu & 7.78 & 29.5 & 4.51 & 0.10 & 2.04 & 1.76 & 0.49 & 0.02 & 20.51 \\
\hline
\end{tabular}

(5'-AATCCAAARACCTTCCTCCC-3') (Rinta-Kanto et al., 2005), the Microcystis-specific 16S rRNA gene was amplified under the following conditions: $95^{\circ} \mathrm{C}$ for $10 \mathrm{~min}$, followed by 45 cycles of $99^{\circ} \mathrm{C}$ for $10 \mathrm{~s}, 55^{\circ} \mathrm{C}$ for $30 \mathrm{~s}$, and $72{ }^{\circ} \mathrm{C}$ for $30 \mathrm{~s}$.

Single copy plasmids were prepared as the qPCR standards. A puf $M$ and bacterial 16S rRNA gene fragment were amplified by PCR using the above primers from an AAP bacterium Porphyrobacter BacR (the GenBank accession number EU770255), which was isolated from the cyanobacterium Microcystis aeruginosa PCC7806 culture (our unpublished data). A Microcystis-specific 16S rRNA gene was amplified by PCR with the above primers from $M$. aeruginosa PCC7806. The PCR products were gel-purified and cloned into the pGEM-T vector (Promega) following the manufacturer's instructions. Inserts in the clones were confirmed through PCR using the above specific primers and subsequent electrophoresis. The plasmids, each of which contained one copy of the target gene, were used as qPCR standards. $\mathrm{R}^{2}$ values of the standard curves were $0.994,0.999$, and 0.997 for the pufM, total bacterial 16S rRNA, and Microcystis-specific 16S rRNA genes, respectively.

\section{Results}

\section{Chemical conditions of the two lakes}

Table 1 shows the geochemical parameters of water samples from Lake Taihu and Lake Chaohu. The presence of high concentrations of phosphorus, nitrogen, and chlorophyll $a$ indicated that both lakes were eutrophic (Jin and Tu, 1990). Cyanobacteria and other algae in the samples were identified morphologically using light microscopy. The collected cyanobacterial bloom biomass was found to contain cyanobacteria Microcystis spp. and Planktothrix sp. No other algae were observed in the samples. The ratio of the number of the Microcystis colonies to that of the Planktothrix filaments was more than 100:1. Microcystis spp. was composed mainly of Microcystis aeruginosa, M. flos-aquae, and M. wesenbergii.

\section{Diversity of AAP bacteria}

A total of 110 clones of four pufM gene clone libraries were compared to known pufM genes using BLAST (Table 2). AAP bacteria belonging to Alphaproteobacteria and Betaproteobacteria were found in both lakes (Table 3).
Alphaproteobacteria contained Agrobacterium-, Bradyrhizobium-, Erythrobacter-, Loktanella-, Methylobacterium-, Porphyrobacter-, Roseisalinus-, Rhodopseudomonas-, Rhodobacter-, and Sphingomonas-like bacteria. Betaproteobacteria contained only Rubrivivax-like bacteria. Gammaproteobacterial AAP bacteria, including Allochromatium- and Thiocapsa-like bacteria were found only in Lake Chaohu. In Lake Taihu, $81.5 \%$ of the clones from Microcystis-associated AAP bacteria and $84.6 \%$ of the clones from free-living AAP bacteria were affiliated with Alphaproteobacteria. In Lake Chaohu, $75.0 \%$ of the clones from Microcystis-associated AAP bacteria and $72.5 \%$ of the clones from free-living AAP bacteria were affiliated with Alphaproteobacteria. Among Alphaproteobacterial AAP bacteria, Rhodobacter- and Loktanella-like clusters were predominant in both lakes.

\section{Abundance of AAP bacteria}

The abundance of Microcystis-associated AAP bacteria in Lake Taihu and Lake Chaohu were $18.3 \pm 2.2 \%$ and $11.7 \pm 1.3 \%$, respectively, whereas the abundance of freeliving AAP bacteria in Lake Taihu and Lake Chaohu were $5.1 \pm 0.8 \%$ and $7.9 \pm 0.6 \%$, respectively (Table 4). The abundance of Microcystis-associated AAP bacteria was higher than that of free-living AAP bacteria.

\section{Discussion}

A high diversity of AAP bacteria was observed in the two study eutrophic lakes. Most of the obtained pufM gene sequences were found to be related to Loktanella-, Bradyrhizobium-, Sphingomonas-, Thiocapsa-, Rhodobacter-, and Erythrobacter-like bacteria. The Erythrobacter-like AAP bacterium is distributed across the eutrophic and oligotrophic marine regions, and the Rhodobacter-like AAP bacterium is ubiquitous in the Delaware Estuary (Waidner and Kirchman, 2008). Our data in this study indicated that these two genera were also distributed in freshwater lakes.

Alphaproteobacteria were the dominant AAP bacteria in the two eutrophic lakes. This was different from the previous reports that found Betaproteobacterial AAP bacteria to be the predominant bacteria in freshwater bodies (Karr et al., 2003; Waidner and Kirchman, 2005, 2008). The distribution of AAP bacteria can be influenced by various factors, such as light, UV, water chemistry, salinity, chlorophyll $a$, and particles (Jiao et al., 2007; 
Table 2. BLAST analysis of all representative sequences in pufM gene clone libraries. Clone sequences showing more than $97 \%$ similarity were considered to be the same group. AT, clone library of AAP bacteria associated with Microcystis colonies from Lake Taihu. FT, clone library of free-living AAP bacteria from Lake Taihu. AC, clone library of AAP bacteria associated with Microcystis colonies from Lake Chaohu. FC, clone library of free-living AAP bacteria from Lake Chaohu.

\begin{tabular}{|c|c|c|c|c|c|c|c|}
\hline \multirow{2}{*}{$\begin{array}{l}\text { Accession } \\
\text { number }\end{array}$} & \multirow[b]{2}{*}{ Nearest relative (accession number) } & \multirow[b]{2}{*}{ Score } & \multirow{2}{*}{$\begin{array}{l}\text { Similarity } \\
(\%)\end{array}$} & \multicolumn{4}{|c|}{ Number of clones of each group in four clone libraries } \\
\hline & & & & AT & FT & $\mathrm{AC}$ & FC \\
\hline FJ589072 & Rhodobacter veldkampii (AB062784) & 191 & 84 & 2 & 0 & 4 & 0 \\
\hline FJ589073 & $\begin{array}{l}\text { Methylobacterium radiotolerans } \\
\text { strain ATCC } 27329 \text { (DQ017883) }\end{array}$ & 257 & 90 & 0 & 0 & 0 & 3 \\
\hline FJ589074 & Erythrobacter litoralis (AB010981) & 142 & 82 & 1 & 0 & 0 & 0 \\
\hline FJ589075 & Sphingomonas sp. PB180 (AY853584) & 182 & 84 & 0 & 0 & 1 & 0 \\
\hline FJ589076 & $\begin{array}{l}\text { Roseisalinus antarcticus strain } \\
\text { DSM } 11466 \text { (DQ915725) }\end{array}$ & 224 & 87 & 3 & 0 & 4 & 0 \\
\hline FJ589078 & Loktanella sp. NP29 (EU196353) & 191 & 84 & 0 & 0 & 0 & 1 \\
\hline FJ589079 & Sphingomonas sp. PB229 (AY853585) & 198 & 86 & 5 & 0 & 1 & 0 \\
\hline FJ589080 & $\begin{array}{l}\text { Bradyrhizobium denitrificans strain } \\
\text { USDA } 4427 \text { (DQ017871) }\end{array}$ & 222 & 85 & 1 & 0 & 1 & 0 \\
\hline FJ589082 & Rubrivivax gelatinosus (AY234384) & 246 & 89 & 0 & 0 & 4 & 0 \\
\hline FJ589083 & Rubrivivax gelatinous (AY234384) & 219 & 87 & 0 & 0 & 1 & 0 \\
\hline FJ589084 & Rubrivivax gelatinosus (AY234384) & 219 & 87 & 4 & 0 & 2 & 1 \\
\hline FJ589085 & Porphyrobacter neustonensis (AB011073) & 219 & 90 & 2 & 0 & 0 & 0 \\
\hline FJ589086 & Rhodobacter azotoformans (AB062783) & 141 & 80 & 0 & 0 & 0 & 3 \\
\hline FJ589087 & Loktanella sp. NP29 (EU196353) & 213 & 86 & 0 & 1 & 0 & 1 \\
\hline FJ589088 & $\begin{array}{l}\text { Rhodobacteraceae bacterium } \\
\text { BS110 (EU009369) }\end{array}$ & 233 & 88 & 0 & 2 & 0 & 0 \\
\hline FJ589089 & unknown & 113 & 80 & 0 & 1 & 0 & 0 \\
\hline FJ589090 & unknown & 145 & 80 & 0 & 0 & 0 & 1 \\
\hline FJ589091 & $\begin{array}{l}\text { Rhodobacteraceae bacterium } \\
\text { BS110 (EU009369) }\end{array}$ & 189 & 81 & 0 & 0 & 0 & 1 \\
\hline FJ589093 & Methylobacterium sp. 4-46 (CР000943) & 219 & 87 & 0 & 3 & 0 & 0 \\
\hline FJ589094 & Rubrivivax gelatinosus strain S1 (AY234384) & 224 & 87 & 0 & 0 & 0 & 1 \\
\hline FJ589096 & Agrobacterium sanguineum (AB011074) & 171 & 85 & 1 & 0 & 0 & 0 \\
\hline FJ589097 & Rhodobacter azotoformans (AB062783) & 224 & 87 & 1 & 0 & 0 & 0 \\
\hline FJ589098 & Erythrobacter longus (D50648) & 152 & 81 & 0 & 1 & 0 & 0 \\
\hline FJ589099 & Bradyrhizobium sp. BTAi1 (CP000494) & 174 & 83 & 0 & 0 & 1 & 0 \\
\hline FJ589100 & Bradyrhizobium sp. BTAi1 (CP000494) & 163 & 82 & 1 & 0 & 0 & 0 \\
\hline FJ589101 & Erythrobacter litoralis (AB010981) & 141 & 82 & 1 & 0 & 0 & 0 \\
\hline FJ589102 & $\begin{array}{l}\text { Rhodobacteraceae bacterium } \\
\text { BS110 (EU009369) }\end{array}$ & 174 & 83 & 0 & 0 & 0 & 1 \\
\hline FJ589103 & Loktanella sp. NP29 (EU196353) & 191 & 84 & 0 & 0 & 0 & 2 \\
\hline FJ589104 & Rhodobacter azotoformans (AB062783) & 150 & 81 & 0 & 0 & 0 & 1 \\
\hline FJ589105 & $\begin{array}{c}\text { Porphyrobacter tepidarius } \\
\text { MBIC3363 (AB020599) }\end{array}$ & 250 & 92 & 0 & 0 & 0 & 2 \\
\hline FJ589106 & Allochromatium vinosum (AB011811) & 185 & 84 & 0 & 0 & 0 & 1 \\
\hline FJ589107 & $\begin{array}{c}\text { Porphyrobacter tepidarius } \\
\text { MBIC3363 (AB020599) }\end{array}$ & 183 & 85 & 0 & 0 & 0 & 1 \\
\hline FJ589108 & Allochromatium vinosum (AB011811) & 147 & 80 & 0 & 0 & 0 & 1 \\
\hline FJ589109 & Loktanella sp. NP29 (EU196353) & 191 & 84 & 0 & 4 & 0 & 1 \\
\hline FJ589110 & Rubrivivax gelatinosus (AY234384) & 224 & 87 & 0 & 2 & 0 & 1 \\
\hline FJ589111 & Rhodobacter azotoformans (AB062783) & 202 & 85 & 0 & 2 & 0 & 0 \\
\hline FJ589112 & Rhodopseudomonas lichen (B241419) & 206 & 86 & 0 & 1 & 0 & 2 \\
\hline FJ589113 & unknown & & & 0 & 1 & 0 & 0 \\
\hline FJ589114 & Loktanella sp. NP29 (EU196353) & 195 & 85 & 0 & 2 & 0 & 0 \\
\hline FJ589118 & Loktanella sp. NP29 (EU196353) & 219 & 87 & 2 & 0 & 7 & 1 \\
\hline FJ589119 & Sphingomonas sp. PB56 (AY853583) & 111 & 78 & 0 & 0 & 1 & 0 \\
\hline FJ589120 & Rubrivivax gelatinosus (D16822) & 235 & 88 & 1 & 0 & 0 & 0 \\
\hline FJ589121 & Rhodopseudomonas lichen (AB241419) & 206 & 86 & 0 & 2 & 0 & 0 \\
\hline FJ589122 & Sphingomonas sp. PB180 (AY853584) & 196 & 86 & 0 & 1 & 0 & 0 \\
\hline FJ589123 & Sphingomonas sp. PB180 (AY853584) & 185 & 85 & 0 & 1 & 0 & 0 \\
\hline FJ589124 & Rhodobacter azotoformans (AB062783) & 174 & 82 & 0 & 2 & 0 & 0 \\
\hline FJ589125 & Loktanella sp. NP29 (EU196353) & 196 & 85 & 1 & 0 & 1 & 0 \\
\hline FJ589126 & Thiocapsa imhoffii strain SC5 (EU910945) & 141 & 80 & 0 & 0 & 0 & 2 \\
\hline FJ589127 & Loktanella sp. NP29 (EU196353) & 167 & 82 & 0 & 0 & 0 & 1 \\
\hline FJ589128 & Rhodobacter blasticus (D50649) & 219 & 87 & 1 & 0 & 0 & 0 \\
\hline
\end{tabular}


Table 3. Percentage of clones belonging to different types of AAP bacteria in each pufM gene clone library according to BLAST analysis of pufM genes in Table 2.

\begin{tabular}{|c|c|c|c|c|c|}
\hline Type & Taxon $^{\mathrm{a}}$ & AT & FT & $\mathrm{AC}$ & $\mathrm{FC}$ \\
\hline Rhodobacter-like & Alpha & 14.8 & 23.1 & 14.3 & 20.7 \\
\hline Methylobacterium-like & Alpha & 0 & 11.5 & 0 & 10.3 \\
\hline Erythrobacter-like & Alpha & 7.4 & 3.8 & 0 & 0 \\
\hline Sphingomonas-like & Alpha & 18.5 & 7.7 & 10.7 & 0 \\
\hline Roseisalinus-like & Alpha & 11.1 & 0 & 14.3 & 0 \\
\hline Loktanella-like & Alpha & 11.1 & 26.9 & 28.6 & 24.1 \\
\hline Bradyrhizobium-like & Alpha & 7.4 & 0 & 7.1 & 0 \\
\hline Porphyrobacter-like & Alpha & 7.4 & 0 & 0 & 10.3 \\
\hline Rhodopseudomonas-like & Alpha & 0 & 11.5 & 0 & 6.9 \\
\hline Agrobacterium-like & Alpha & 3.7 & 0 & 0 & 0 \\
\hline Rubrivivax-like & Beta & 18.5 & 7.7 & 25.0 & 10.3 \\
\hline Allochromatium-like & Gamma & 0 & 0 & 0 & 6.9 \\
\hline Thiocapsa-like & Gamma & 0 & 0 & 0 & 6.9 \\
\hline Unknown & - & 0 & 7.7 & 0 & 3.4 \\
\hline
\end{tabular}

a Alpha, Beta, and Gamma designations refer to the subclasses of proteobacteria.

Table 4. AAP bacterial abundance determined by qPCR in two lakes.

\begin{tabular}{lcccc}
\hline & $\begin{array}{c}\text { Free-living AAP bacteria } \\
(\text { cells.mL }\end{array}$ & $\begin{array}{c}\text { Free-living bacteria } \\
\left(\text { cells.mL } \mathrm{mL}^{-1}\right)\end{array}$ & $\begin{array}{c}\text { Percentage of free-living } \\
\text { AAP bacteria }^{\mathrm{a}}\end{array}$ & $\begin{array}{c}\text { Percentage of } \\
\text { Microcystis-associated } \\
\text { AAP bacteria }\end{array}$ \\
\hline Lake Taihu & $2.3 \mathrm{E}+06( \pm 69097)$ & $4.6 \mathrm{E}+07( \pm 5444722)$ & $5.1 \pm 0.8$ & $18.3 \pm 2.2$ \\
Lake Chaohu & $1.3 \mathrm{E}+05( \pm 29399)$ & $1.6 \mathrm{E}+06( \pm 483356)$ & $7.9 \pm 0.6$ & $11.7 \pm 1.3$ \\
\hline
\end{tabular}

apercentage of free-living AAP bacteria in total free-living bacteria.

${ }^{\mathrm{b}}$ Percentage of Microcystis-associated AAP bacteria in total Microcystis-associated bacteria.

Waidner and Kirchman, 2008). The difference in environmental conditions between the eutrophic lakes in this study and other freshwater lakes in previous reports may result in the different AAP bacterial community structure.

For the determination of AAP bacterial abundance, the qPCR method has been demonstrated to be reliable and consistent with time-series observation-based infrared epifluorescence microscopy (TIREM) protocol (Jiao et al., 2007; Jiang et al., 2008). The abundance of AAP bacteria in both Lake Taihu and Lake Chaohu was higher than the reported level $(<1 \%)$ in other eutrophic freshwater bodies, but was lower than those in oligotrophic and mesotrophic freshwater bodies (10-80\%) (Mašín et al., 2008). The abundance of AAP bacteria associated with Microcystis colonies was comparable to that associated with particles in estuaries (12-24\%) (Waidner and Kirchman, 2007, 2008).

In contrast with previous reports on the predominance of Betaproteobacteria in freshwater lakes, Alphaproteobacteria were found to be predominant in AAP bacteria in the two cyanobacterial bloom-forming lakes in this study. The abundance of AAP bacteria in the two bloom-forming lakes was also higher than the previously reported level in other eutrophic freshwater bodies. Furthermore, the abundance of AAP bacteria associated with Microcystis colonies was higher than that in free-living bacterioplankton. These data suggested that the formation of cyanobacterial bloom might affect the distribution of AAP bacteria in the eutrophic water bodies.
In this study, AAP bacteria were found to be associated with Microcystis colonies. This is consistent with the previous reports on the association between AAP bacteria and algae. AAP bacteria closely associated with algae have been isolated from cyanobacterial mats in springs (Yurkov and Gorlenko, 1990), macroalgae (Shiba, 1991), and dinoflagellates (Lafay et al., 1995; Prokic et al., 1998; Allgaier et al., 2003). Moreover, AAP bacteria have been found to be positively correlated with oxygenic phototrophs in the sea (Béjà et al., 2002; Jiao et al., 2007). The abundance of Microcystis-associated AAP bacteria was found to be higher than that of free-living AAP bacteria in this study. This indicated that growing cyanobacterium may provide suitable growth conditions in the mucilage layer for AAP bacteria. AAP bacteria most likely rely on exudants produced by oxygenic photoautotrophs to supply reductants and metabolize organic carbon produced by the phytoplankton, and their photosynthetic efficiency and spectral light utilization is similar to that of the oxygenic phototrophs (Béjà et al., 2002; Jiao et al., 2007). Oxygen is necessary for aerobic phototrophic bacterial photosynthesis (Yurkov and Beatty, 1998). The AAP bacterium Erythorbacter species OCh 114 cannot obtain energy from light under the conditions of oxygen supply lower than the minimum level (Harashima et al., 1987). It is possible that the suitable light condition and supply of essential nutrient substances and sufficient oxygen from cyanobacterial cells favored the growth of AAP bacteria in the mucilage of Microcystis. This hypothesis deserves further 
investigation. Bacterial-algal interactions are of potentially great importance in regulating algal population dynamics in nature and may therefore play an important role in the formation and development of algal blooms (Kodama et al., 2006). Further studies are also needed to explore the possible stimulative or inhibitory effect of associated AAP bacteria on the growth of Microcystis.

Acknowledgements. The authors are grateful to the two referees for their valuable comments. This study was financially supported by the National Basic Research Program of China (973 Program, 2008CB418004) and the Natural Science Foundation of Jiangsu Province (BK2007150).

\section{References}

Allgaier M., Uphoff H., Felske A. and Wagner-Dobler I., 2003. Aerobic anoxygenic photosynthesis in Roseobacter clade bacteria from diverse marine habitats. Appl. Environ. Microbiol., 69, 5051-5059.

Béjà O., Suzuki M.T., Heidelberg J.F., Nelson W.C., Preston C.M., Hamada T., Eisen J.A., Fraser C.M. and Delong E.F., 2002. Unsuspected diversity among marine aerobic anoxygenic phototrophs. Nature, 415, 630-633.

Brunberg A.K., 1999. Contribution of bacteria in the mucilage of Microcystis spp. (cyanobacteria) to benthic and pelagic bacterial production in a hypereutrophic lake. FEMS Microbiol. Ecol., 29, 13-22.

Cottrell M.T., Mannino A. and Kirchman D.L., 2006. Aerobic anoxygenic phototrophic bacteria in the Mid-Atlantic Bight and the North Pacific Gyre. Appl. Environ. Microbiol., 72, 557-564.

Eiler A., 2006. Evidence for the ubiquity of mixotrophic bacteria in the upper ocean: implications and consequences. Appl. Environ. Microbiol., 72, 7431-7437.

Harashima K., Kawazoe K., Yoshida I. and Kamata H., 1987. Light stimulated aerobic growth of Erythrobacter species OCh 114. Plant Cell Physiol., 28, 365-374.

$\mathrm{Hu}$ H.J. and Wei Y.X., 2006. The freshwater algae of China: Systematics, taxonomy and ecology, Scientific Press, China (in Chinese).

Hu Y., Du H., Jiao N.Z. and Zeng Y., 2006. Abundant presence of the gamma-like proteobacterial pufM gene in oxic seawater. FEMS Microbiol. Lett., 263, 200-206.

Jiang H., Dong H., Yu B., Li Y., Ji S., Liu X. and Zhang C., 2007. Microbial response to salinity change in Lake Chaka, a hypersaline lake on Tibetan Plateau. Environ. Microbiol., 9, 2603-2621.

Jiang H., Dong H., Yu B., Ye Q., Shen J., Rowe H. and Zhang C., 2008. Dominance of putative marine benthic archaea in Qinghai Lake, northwestern China. Environ. Microbiol., 10, 2355-2367.

Jiang H.C., Dong H.L., Yu B.S., Lv G., Deng S.C., Wu Y.J., Dai M.H. and Jiao N.Z., 2009. Abundance and diversity of aerobic anoxygenic phototrophic bacteria in saline lakes on the Tibetan plateau. FEMS Microbiol. Ecol., 67, 268-278.

Jiao N.Z., Zhang Y., Zeng Y.H., Hong N., Liu R.L., Chen F. and Wang P.X., 2007. Distinct distribution pattern of abundance and diversity of aerobic anoxygenic phototrophic bacteria in the global ocean. Environ. Microbiol., 9, 3091-3099.
Jin X.C. and Tu Q.Y., 1990. Handbook of eutrophication investigation of lake (2nd edn.), China Environmental Science Press, Beijing, China (in Chinese).

Karl D.M., 2002. Microbiological oceanography - hidden in a sea of microbes. Nature, 415, 590-591.

Karr E.A., Sattley W.M., Jung D.O., Madigan M.T. and Achenbach L.A., 2003. Remarkable diversity of phototrophic purple bacteria in a permanently frozen Antarctic lake. Appl. Environ. Microbiol., 69, 4910-4914.

Kodama M., Doucette G.J. and Green D.H., 2006. Relationships between bacteria and harmful algae. In: Granéli E. and Turner J.T. (eds.), Ecology of harmful algae, 189, Springer-Verlag, Berlin Heidelberg, 243-255.

Kolber Z.S., Van Dover C.L., Niederman R.A. and Falkowski P.G., 2000. Bacterial photosynthesis in surface waters of the open ocean. Nature, 407, 177-179.

Kolber Z.S., Plumley F.G., Lang A.S., Beatty J.T., Blankenship R.E., VanDover C.L., Vetriani C., Kobližek M., Rathgeber C. and Falkowski P.G., 2001. Contribution of aerobic photoheterotrophic bacteria to the carbon cycle in the ocean. Science, 292, 2492-2495.

Lafay B., Ruimy R., Detraubenberg C.R., Breitmayer V., Gauthier M.J. and Christen R., 1995. Roseobacter algicola sp. nov., a new marine bacterium isolated from the phycosphere of the toxin-producing dinoflagellate Prorocentrum lima. Int. J. Syst. Bacteriol., 45, 290-296.

Lami R., Cottrell M.T., Ras J., Ulloa O., Obernosterer I., Claustre H., Kirchman D.L. and Lebaron P., 2007. High abundances of aerobic anoxygenic photosynthetic bacteria in the South Pacific Ocean. Appl. Environ. Microbiol., 73, 4198-4205.

Mašín M., Nedoma J., Pechar L. and Koblížek M., 2008. Distribution of aerobic anoxygenic phototrophs in temperate freshwater systems. Environ. Microbiol., 10, 19881996.

Nadkarni M., Martin F.E., Jacques N.A. and Hunter N., 2002. Determination of bacterial load by real-time PCR using a broad range (universal) probe and primer set. Microbiology, 148, 257-266.

Prokic I., Brummer F., Brigge T., Gortz H.D., Gerdts G., Schutt C., Elbrachter M. and Muller W.E.G., 1998. Bacteria of the genus Roseobacter associated with the toxic dinoflagellate Prorocentrum lima. Protist, 149, 347-357.

Rinta-Kanto J.M., Ouellette A.J., Boyer G.L., Twiss M.R., Bridgeman T.B. and Wilhelm S.W., 2005. Quantification of toxic Microcystis spp. during the 2003 and 2004 blooms in western Lake Erie using quantitative real-time PCR. Environ. Sci. Technol., 39, 4198-4205.

Schwalbach M.S. and Fuhrman J.A., 2005. Wide-ranging abundances of aerobic anoxygenic phototrophic bacteria in the world ocean revealed by epifluorescence microscopy and quantitative PCR. Limnol. Oceanogr., 50, 620-628.

Shiba T., 1991. Roseobacter litoralis gen. nov. sp. nov., and Roseobacter denitrificans sp. nov., aerobic pink-pigmented bacteria which contain bacteriochlorophyll a. Syst. Appl. Microbiol., 14, 140-145.

Tillett D. and Neilan B.A., 2000. Xanthogenate nucleic acid isolation from cultured and environmental cyanobacteria. J. Phycol., 36, 251-258.

Waidner L.A. and Kirchman D.L., 2005. Aerobic anoxygenic photosynthesis genes and operons in uncultured bacteria in the Delaware River. Environ. Microbiol., 7, 1896-1908. 
Waidner L.A. and Kirchman D.L., 2007. Aerobic anoxygenic phototrophic bacteria attached to particles in turbid maters of the Delaware and Chesapeake estuaries. Appl. Environ. Microbiol., 73, 3936-3944.

Waidner L.A. and Kirchman D.L., 2008. Diversity and distribution of ecotypes of the aerobic anoxygenic phototrophy gene, pufM, in the Delaware estuary. Appl. Environ. Microbiol., 74, 4012-4021.

Worm J. and Søndergaard M., 1998. Dynamics of heterotrophic bacteria attached to Microcystis spp. (Cyanobacteria). Aquat. Microb. Ecol., 14, 19-28.
Yurkov V.V. and Beatty J.T., 1998. Aerobic anoxygenic phototrophic bacteria. Microbiol. Mol. Biol. Rev., 62, 695724.

Yurkov V.V. and Gorlenko V.M., 1990. Erythrobacter sibiricus sp. nov., a new freshwater aerobic species containing bacteriochlorophyll a. Microbiology, 59, 85-89.

Yurkova N., Rathgeber C., Swiderski J., Stackebrandt E., Beatty J.T., Hall K.J. and Yurkov V., 2002. Diversity, distribution and physiology of the aerobic phototrophic bacteria in the mixolimnion of a meromictic lake. FEMS Microbiol. Ecol., 40, 191-204. 